\title{
Personnel Control Practices in Insurance Companies of Nepal
}

\author{
Jitendra Pd. Upadhyay, Ph.D. \\ Associate Professor, Nepal Commerce Campus, TU \\ Board of Director, Rastriya Banijya Bank Ltd \\ jupadhaya@yahoo.com
}

\begin{abstract}
Background - Personnel controlling is used to achieve best possible use of employees and their development to get the maximum benefit for the company. It will be present not only in the human resource planning and staff assessment, but also in selection, professional development, health and safety

Purpose - The purpose of the study is to analyze the practices of personnel control in Insurance Companies of Nepal

Methodology - Due to the specific nature of the research objectives, descriptive cum analytical research design has been used.
\end{abstract}

Findings - All the insurance companies have applied the personnel control approaches in their company.

Keywords - Personnel control

Paper Type - Research paper.

\section{Introduction}

Personnel control is used to achieve the best possible use of employees and their development to get the maximum benefit for the company. Information collection and processing of personal information is its main role. The elements of personnel controlling will be present not only in the human resource planning and staff assessment, but also in selection, professional development, health and safety. It can also affect labour relations and measures of performance and productivity. Depending on the management objectives for the personnel controlling subsystem, its function could be delegated to specific employee ("controller"). He/she could have advisory functions that allows to collect, analyze, report and prepare of a decision. He/she could also have management powers, which gives him a much better decision-making capabilities, and allows closer 
cooperation with other organizational units. The basic features of personnel control are:

- Treatment of staff as a vital business asset,

- Treatment of workers as a source of competitiveness for the organization,

- Shift from the perception of staff regarded only as a source of costs,

- Merging of HR strategy with overall business strategy,

- $\quad$ Active inclusion of line managers in the personnel management.

Organization goals can be accomplished by working with their employee. It is important, therefore, for the organization to ensure that employees are performing as they are supposed to. The most explicit ways to control employee's behavior are by direct supervision, performance appraisals, discipline, management information system, management by objectives and decision support system (Robbins, 2000).

\section{a) Direct Supervision}

On a day-to-day basis, managers oversee employees' work and correct problems as they occur. The supervisor stops an employee from taking an unnecessary risk when operating his or her equipment may point out the correct way to perform the task and tell the employee to do it the correct way in the future.

\section{b) Performance Appraisal}

Performance appraisal is a process of evaluating individuals in order to arrive at objective human resource decisions. Organization uses performance appraisal approach to control employee behavior.

\section{c) Discipline}

When an employee's performance regularly is not up to par or if an employee consistently ignores the organization's standards and regulations, it is necessary to use discipline as a way to control behavior. Discipline refers to actions taken by a management to enforce the organization's standards and regulations, i.e. discipline is used to control and correct.

\section{d) Management by Objectives (MBO)}

MBO is a philosophy of management which seeks to judge the performance of managers on the basis of their success in achieving the objectives, they have established through consultation with their superiors. Performance improvement efforts under management by objective are focused upon the goals to be achieved by managers rather than upon the activities performed or the traits exhibited by them in connection with their assigned duties.

MBO is a system involving a cycle that begins with a study of the organization's common goals return to that point. The MBO system thus enables managers to plan and measure their own performance, as well as that of their subordinates, in terms of concrete results. It shifts the emphasis from later appraisal to self analysis and from focus on the past to focus on the future. 


\section{e) Management Information System}

A management information system is another tool for personnel control, which is an ongoing future oriented structure designed to generate, process, store and later retrieve information to aid decision-making and controlling in an organization. It is a system that gathers comprehensive data, organizes and summarizes it in a form valuable to managers, and provides those managers with the information they need to do their work.

\section{Insurance Companies in Nepal}

Insurance is an arrangement by which a company or the state undertakes to provide a guarantee of compensation for specified loss, damage, illness or death in return for payment of a specified premium. It is necessary to develop insurance business in compliance with national need by embracing the globally accepted insurance norms to provide economic protection to all class of the people against natural and social risks while embracing the globally accepted insurance norms. Rights and interests of the insured are being safeguarded by regulating the insurance business through development, regularization thereby making the insurance business competitive and trustworthy in the delivery of quality and reliable insurance services to the public. Insurance companies is a company that offers insurance policies to the public, either by selling directly to an individual or through another source such as an employee's benefit plan. An insurance company is usually comprised of multiple insurance agents. Insurance company may be classified into the following categories:

Classification on the basis of nature of insurance

- $\quad$ Life Insurance

- $\quad$ Fire Insurance

- Marine Insurance

- Social Insurance

- $\quad$ Miscellaneous Insurance

Classification from business point of view

- $\quad$ Life Insurance

- $\quad$ General Insurance

Classification from risk point of view

- Personal Insurance

- Property Insurance

- $\quad$ Liability Insurance

- $\quad$ Fidelity Guarantee Insurance

The Insurance Committee, established on 14th May, 1969, has been carrying out operations as a regulatory agency by systemizing, regulating, developing, and controlling the insurance business. Currently, there are 27 insurance companies in Nepal out of which 9 companies have been carrying out life insurance business, 17 companies involved in 
non-life insurance and 1 insurance company is engaged in reinsurance. According to figures of ownership structure of insurance companies, three are working as branches of foreign insurance companies, three on joint investment with foreign companies, 18 on private ownership, and two on Government ownership.

Table 1

Existing Status of Insurance Companies

\begin{tabular}{lllll}
\hline Types of Insurance Companies & Non-life & Life & Reinsurance & Total \\
\hline Government & 1 & 1 & - & 2 \\
Private/Public & 13 & 5 & - & 18 \\
Foreign & 2 & 1 & - & 3 \\
Joint & 1 & 2 & 1 & 4 \\
Total & 17 & 9 & 1 & 27 \\
\hline
\end{tabular}

Source: Insurance Board

\section{Objective}

The main objective is to analyze the practices of personnel control in Insurance Companies of Nepal.

\section{Methodology Used}

This research has followed both descriptive and analytical approach of research. A questionnaire survey was conducted for getting the answer of research questions. The questionnaire survey includes 20 questions. Questionnaires were distributed to 20 top, middle and lower level managers with gender wise of various departments of each company. In order to increase the reliability and number of responses, personal visits to each and every respondent were made to distribute and collect the questionnaire. The primary data has been analyzed using different statistical tools, like means, standard deviation; and coefficient of variance. Five scale Likert Scale has been used for analysis on which 1 represented worst and 5 represented best.

There are total of twenty seven insurance companies in Nepal, which constitutes the population of the study. For this study, only seven insurance companies, i.e. Rastriya Beema Sansthan (RBS), Premier Insurance Company (PIC), American Life Insurance Company (ALIC), Nepal Life Insurance Company (NLIC), Prime Life Insurance Company (PLIC), Sikhar Insurance Company (SIC) and Sagarmatha Insurance Company (SMIC) have been selected as sample insurance companies. Selection of sample is based on judgmental basis.

Cronbach's Alpha test has been done to test the reliability of data. Each and every variable have been tested and it was found that every variable reliability test was above $83 \%$. 
Table 2

Brief Profile of Sampled Insurance Companies

\begin{tabular}{llll}
\hline Name of the Insurance Companies & \multicolumn{1}{c}{ Types } & Established Date & \multicolumn{1}{c}{ Ownership } \\
\hline Rastriya Beema Sansthan & Life/Non-life & December 1968 & Government \\
Premier Insurance Company & Non-life & April 1994 & Private/Public \\
American Life Insurance Company & Life & August 2001 & Foreign \\
Nepal Life Insurance Company & Life & January 1988 & Joint-venture \\
Prime Life Insurance Company & Life & June 2007 & Private/Public \\
Shikhar Insurance Company & Non Life & March 2004 & Private/Public \\
Sagarmatha Insurance Company & Non-Life & 1996 & Joint-venture \\
\hline
\end{tabular}

Respondent's Profile

In this section, characteristics of respondents have been presented first gender wise and then designation wise.

Table 3

Gender Wise Respondents

\begin{tabular}{lccccc}
\hline Name of the Insurance Companies & $\begin{array}{c}\text { Male } \\
\text { (No.) }\end{array}$ & $\%$ & $\begin{array}{c}\text { Female } \\
\text { (No.) }\end{array}$ & $\%$ & Total \\
\hline Rastriya Beema Sansthan & 14 & 70 & 6 & 30 & 20 \\
Premier Insurance Company & 12 & 60 & 8 & 40 & 20 \\
American Life Insurance Company & 15 & 75 & 5 & 25 & 20 \\
Nepal Life Insurance Company & 13 & 65 & 7 & 35 & 20 \\
Prime Life Insurance Company & 12 & 60 & 8 & 40 & 20 \\
Shikhar Insurance Company & 13 & 65 & 7 & 35 & 20 \\
Sagarmatha Insurance Company & 14 & 70 & 6 & 30 & 20 \\
\hline Total & $\mathbf{9 3}$ & $\mathbf{6 6 . 4 3}$ & $\mathbf{4 7}$ & $\mathbf{3 3 . 5 7}$ & $\mathbf{1 4 0}$ \\
\hline
\end{tabular}

Majority of respondents were males i.e. $66.43 \%$. But female respondents were also satisfactory i.e. $33.57 \%$ or in number 47 out of 140 . Highest number of male respondents was in ALIC and females were in PIC and PLIC i.e. 15 and 8 in number out of 20 respectively. Similarly lowest number of males respondents were in PIC \& PLIC and female were in ALIC i.e. is 12 and 5 in number respectively. The reason behind low number of female respondents is that all companies have high number of male employee.

Table 4

Designation Wise Respondents

\begin{tabular}{lccccccc}
\hline Name of the Insurance Co. & $\begin{array}{c}\text { Lower } \\
\text { Level }\end{array}$ & $\%$ & $\begin{array}{c}\text { Middle } \\
\text { Level }\end{array}$ & $\%$ & $\begin{array}{c}\text { Higher } \\
\text { Level }\end{array}$ & $\%$ & Total \\
\hline Rastriya Beema Sansthan & 4 & 20 & 10 & 50 & 6 & 30 & 20 \\
\hline Journal of Business and Social Sciences (JBSS) & & & & & $\sim 31 \sim$
\end{tabular}




\begin{tabular}{lccccccc} 
Premier Insurance Company & 5 & 25 & 11 & 55 & 4 & 20 & 20 \\
American Life Insurance Co. & 4 & 20 & 11 & 55 & 5 & 25 & 20 \\
Nepal Life Insurance Co. & 5 & 25 & 9 & 45 & 6 & 30 & 20 \\
Prime Life Insurance Co. & 4 & 20 & 10 & 50 & 6 & 30 & 20 \\
Shikhar Insurance Company & 5 & 25 & 11 & 55 & 4 & 20 & 20 \\
Sagarmatha Insurance Co. & 4 & 20 & 9 & 45 & 7 & 35 & 20 \\
\hline Total & 31 & 22.14 & 71 & 50.71 & 38 & 27.14 & 140 \\
\hline
\end{tabular}

Above table presents the characteristics of respondents' designation wise. Majority respondents were found in Middle Level, i.e. $50.71 \%$. Only $22.14 \%$ respondents were found in Lower Level. In SMIC Higher Level of respondents were high in number, i.e. 7 compared to other insurance companies.

\section{Analysis and Findings}

The table 5 explains the different elements of personnel control in different Insurance Companies.

\section{Table 5}

Elements of Personnel Control in Insurance Companies

\begin{tabular}{lccccccc}
\hline Insurance Companies & RBS & PIC & ALIC & NLIC & PLIC & SIC & SMIC \\
\hline PP & 4.30 & 4.20 & 4.30 & 4.40 & 4.20 & 4.20 & 4.20 \\
ARD & 4.31 & 4.42 & 4.08 & 4.00 & 4.10 & 4.22 & 4.20 \\
EP & 3.20 & 3.17 & 3.33 & 3.50 & 3.45 & 3.35 & 3.24 \\
CQ & 3.17 & 3.33 & 3.22 & 3.21 & 3.11 & 3.21 & 3.24 \\
SD & 3.75 & 3.69 & 3.44 & 3.94 & 3.84 & 3.63 & 3.66 \\
PA & 3.75 & 3.25 & 3.38 & 3.69 & 3.49 & 3.52 & 3.35 \\
SAM & 2.90 & 2.89 & 2.85 & 2.95 & 2.90 & 2.75 & 2.85 \\
Total & 25.38 & 24.95 & 24.6 & 25.69 & 25.09 & 24.88 & 24.74 \\
Average & 3.625 & 3.56 & 3.51 & 3.67 & 3.58 & 3.55 & 3.53 \\
Standard Deviation & 0.56 & 0.57 & 0.50 & 0.50 & 0.49 & 0.53 & 0.51 \\
Coefficient of Variance & 15.45 & 16.01 & 14.25 & 13.62 & 13.69 & 14.93 & 14.45 \\
\hline
\end{tabular}

PP (Policies and Practices) define clearly to reduce the incidence of disputes or to eliminate them by means of long-term measures. The value of PP in all the insurance companies has been above average, i.e. 3. In case of NLIC, it has been the highest, i.e. 4.4. This indicates that the policies and practices followed by all the insurance companies to reduce the disputes have been satisfactory. ARD (Authority, Responsibility and Duties) is concerned with the clearly defined company's policies in regard to authority, responsibility and duties of the personnel function. In all the insurance companies, the value has been 
above average, i.e. 3. In case of PIC it has been the highest, i.e. 4.42. This indicates that in PIC has been more concerned about the making policies regarding authority, responsibility and duties of the personnel function. However, the performances of all the insurance companies have been satisfactory.

EP (Employee Participation) focuses on employee participation in formulating goals \& plans and implementing \& evaluating their performance in the insurance companies. In all the insurance companies the value of 'EP' has been above average, i.e. 3 but in case of PIC it has been 3.17 and in case of NLIC, it has been the highest, i.e. 3.5. This indicates that the employee participation of all the insurance companies have been satisfactory.

$\mathrm{CQ}$ (Cost and Quality) analyzes the control system for cost and quality of human resources as they enter and held by the insurance companies. In all the insurance companies, the value has been above average, i.e. 3 . In case of PIC it has been the highest, i.e. 3.33. This indicates that in PIC has been more concerned about the control system for cost and quality of human resources. However, the performances of all other insurance companies also have been satisfactory.

SD (Supervision and Discipline) is concerned with the use of supervision and discipline as a means of personnel control. The value of 'SD' in all the insurance companies has been above average, i.e. 3. It has been the highest in case of NLIC, i.e. 3.94. It has been the lowest in case of SIC, i.e. 3.63. This shows that all the insurance companies have recorded satisfactory performance in terms of 'SD'.

PA (Performance Appraisal) is concerned with the use of proper system of performance appraisal within the insurance companies. Performance of all the insurance companies in terms of 'PA' has been satisfactory because all of them have scored above average i.e. 3. However, Management of RBS seems most committed in using proper system of performance appraisal of all which was warranted by its highest scored 3.75 . In other words, the management of all the insurance companies has been committed to use proper system of performance appraisal.

SAM (Separate Authorized Mechanism) focuses on authorized mechanism for settlement of day-to-day differences and disputes between the employees and supervisory management. The value of SAM in all the insurance companies has been below average i.e. 3. In case of NLIC, it has been the highest, i.e. 2.95 and in case of SIC it has been 2,75 . This indicates that the authorized mechanism for settlement of disputes in all the insurance companies have been somewhat unsatisfactory.

From the table, it has been clear that mean personnel control in all the insurance companies have been above average, i.e. 3 . This clearly indicates that all the insurance companies have been found adhering to the principle of personnel control. Highest value has been observed in case of NLIC, i.e. 3.67. In case of ALIC the value is 3.51.

Journal of Business and Social Sciences (JBSS) 


\section{Conclusion}

Personnel control is a critical aspect in any kind of organizations. With the help of this organization can control their employees and can do different activities for the betterment of their employees. Similarly, organization can be able to achieve their objectives with proper use of employee performance. From the study, performance of all the insurance companies in terms of personnel control has been satisfactory. NLIC has been more concerned about the practices of personnel control as it has highest value of personnel control compared to other insurance companies. Since standard deviation in all the cases has been below 1 and coefficient of variation has been $13.62 \%$ to $16.01 \%$, which indicates that the mean can be safely accepted as representative.

\section{References}

Anthony, R. \& Govindarajan, V. (1998), Management Control System Mc-Graw Hill.

Baker, B. (2010). The Break Through Insurance Agency. How to Multiply Your Income,

Time and Fun Banking and Financial Statistic of Nepal Rastra Bank, 2010

Cooper, R. \& Schindler, S. (2003). Business Research Methods. Tata Mc Graw -

Hill Publishing Company Ltd., New Delhi.

Economic Survey, Nepal (2017).

Emch, F. (1954). Control means Action. Harvard Business Review, July-August, Number 54405.

Glaser, K. (2011). Inside the Insurance Industry

Griffin, W. (2000). Management. AITBS Publishers and Distributors, Delhi.

Ivancevich, M., Donnelly, H. \& Gribson, L.(2001). Management: Principles and Functions. AITBS Publishers and Distributors. Delhi.

Kenneth, A. (2002). Modern Management Control Systems. Text \& Cases.

Pearson Education, Asia.

Kunreuther, H.C., Pouly, M. V. \& Mc Merrow, S. (2012). Insurance and Behavioral

Economics Improving Decisions in the Most Misunderstood Industry.

Levine, Krehbiel \& Berenson. (2004). Business Statistics, A first course. Pearson

Education, Asia.

Saporito, P. L. (2015). Applied Insurance Analysis: A Framework for Driving More Value from Data Analysis, Technologies and Tools.

Siegel, S. \& Castellan, J. (2002). Nonparametric Statistics, for the Behavioral

Sciences. McGraw-Hill International Editions.

Simons, R. (1995). "Control in an age of empowerment," Harvard Business

Review, March-April.

Stevens, J. (2014). Insurance Best Practical Guide for Risk Management, Property, Life and Health with Concepts and coverage.

Vancil, F. (1973). What kind of management control do you need? Harvard

Business Review, March- April, Number 73213.

Wilson, M. (2012). Insurance: Concepts Coverage: Property, Liability, Life, Health and Risk Management.

Wolff, K. \& Pant, R. (2005). Social Science Research and Thesis writing. Buddha Academic Publishers and Distributors Pvt. Ltd., Kathmandu, Nepal. 